\title{
Jetzt schon vormerken und anmelden
}
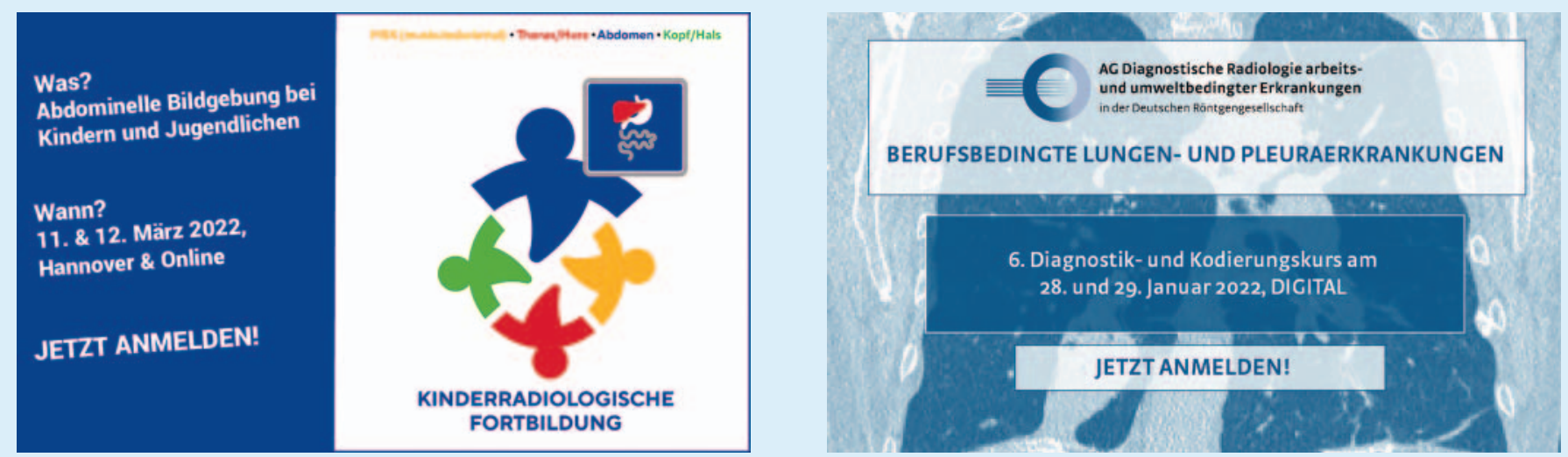

Alle weiteren Informationen erhalten Sie unter www.drg.de > Veranstaltungen > Veranstaltungskalender 